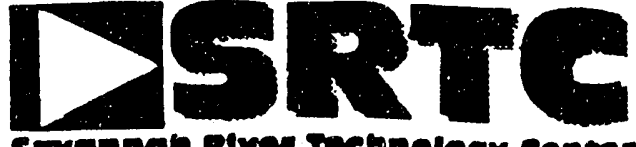

WSRC-TR-92-229 (U)

sarannoh dover Teehnology Contor

Equipment and Matorials Tochnology

KEYWORDS:

304 Stainless Steel

CERT Tests

Low-Level Waste

RETENTION - Permanent

\title{
CONSTANT EXTENSION RATE TENSILE TESTS \\ ON 304L STAINLESS STEEL IN SIMULATED \\ HAZARDOUS LOW-LEVEL WASTE (U)
}

\section{B. J. Wiersma}

SAVANNAH RIVER TECHNOLOGY CENTER

Equipment and Materials Technology Department

Materials Technology Section

Publication Date: April, 1992

Westinghouse Sovannah Rtver Company Savannah River Site

Aiken, SC 29808

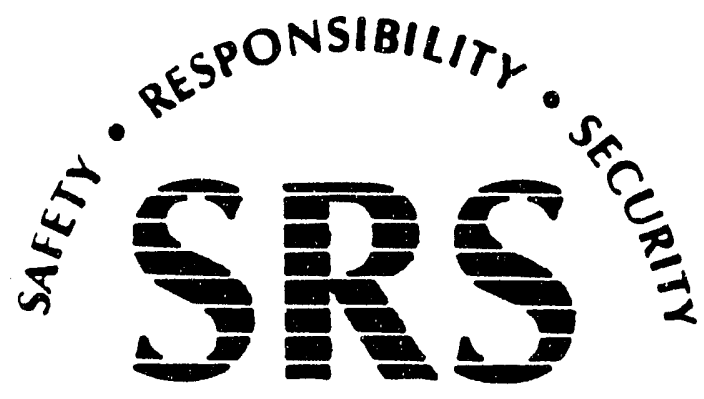




\section{DISCLAIMER}

This report was prepared as an account of work sponsored by an agency of the United States.Government. Neither the United States Government nor any agency thereof, nor any of their employees, makes any warranty, express or implied, or assumes any legal liability or responsibility for the accuracy, completeness, or usefulness of any information, apparatus, product, or process disclosed, or represents that its use would not infringe privately owned rights. Reference herein to any specific commercial product, process, or service by trade name, trademark, manufacturer, or otherwise does not necessarily constitute or imply its endorsement, recommendation, or favoring by the United States Government or any agency thereof. The views and opinions of authors expressed herein do not necessarily state or reflect those of the United States Government or any agency thereof.

This report has been reproduced directly from the best available copy.

Available to DOE and DOE contractors from the Office of Scientific and Technical Information, P.O. Box 62, Oak Ridge, TN 37831; prices available from (615) 576-8401, FTS 626-8401.

Available to the public from the National Technical Information Service, U.S. Department of Commerce, 5285 Port Royal Rd., Springfield, VA 22161. 


\section{CONSTANT EXTENSION RATE TENSILE TESTS ON 304L STAINLESS STEEL IN SIMULATED HAZARDOUS LOW-LEVEL WASTE (U)}

by B. J. Wiersma

Westinghouse Savannah River Company

Savannah River Site

Aiken, South Carolina 29808

This paper was prepared in connection with work done under Contract No. DE-AC09-89SR18035 with the U. S. Department of Energy. By acceptance of this paper, the publisher and/or recipient acknowledges the U. S. Government's right to retain a nonexclusive, royalty-free license in and to any copyright covering this paper, along with the right to reproduce and to authorize others to reproduce all or part of the copyrighted paper. 


\title{
CONSTANT EXTENSION RATE TENSILE TESTS ON 304L STAINLESS STEEL IN SIMULATED FHAZARDOUS LOW-LEVEL WASTE (U)
}

\author{
B. J. Wiersma
}

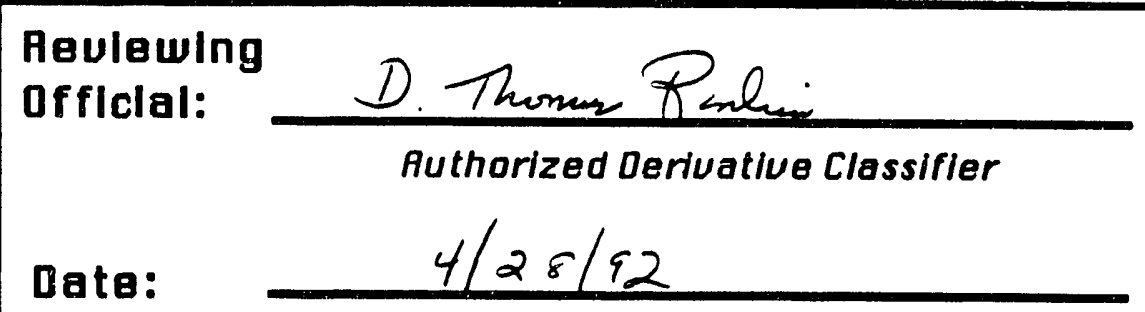

Patenk Status:

This intemal managemeni report $b$

belng transmitted without DOE patent

clearance, and ne tuther dissomination

or publicationatiall be made of the

report without prorepproval of the DOE-8R patont counest.

Westinghouse Savannah Rlver Company Sovannah Rlver Slite Alken, SC 29808

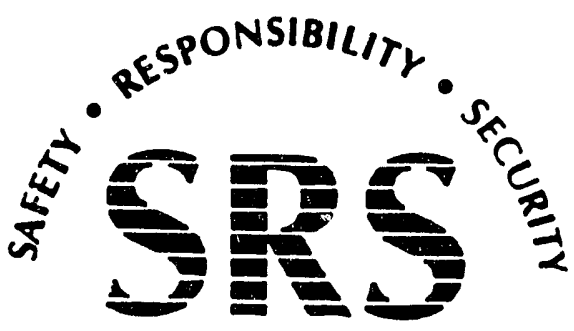


WSRC-TR-92-229 (U)

THIS PAGE INTENTIONALLY LEFT BLANK 


\section{CONTENTS}

$\begin{array}{ll}\text { SUMMARY } & 1\end{array}$

INTRODUCTION 1

EXPERIMENTAL PROCEDURE 2

RESULTS 3

CONCLUSIONS

$\begin{array}{ll}\text { REFERENCES } & 7\end{array}$ 


\section{LIST OF FIGURES}

1 Fracture Surface Of Furnace-sensitized 304L Specimen That Was Immersed In Cask Decontamination Waste $(200 \mathrm{X})$............................................................... 10

2 Fracture Surface Of A537 Specimen That Was Immersed In Cask

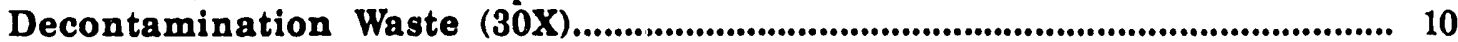

3 Gage Length Of A537 Specimen That Was Immersed In Cask Decontamination

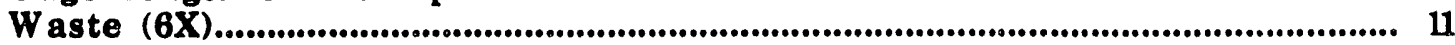

4 Stress vs. Strain Curves For Furnace Sensitized 304L In Different Waste Solutions.

5 Stress vs. Strain Curves For A537 In The Different Waste Solutions............... 13

\section{LIST OF TABLES}

1 Molar Anion Compositions Of Low Level Hazardous Waste........................... 8

2 Analysis of Materials Tested (wt. \%) .............................................................. 8

3 Summary of CERT Results.................................................................................................... 9 


\section{APPROVALS}

$\frac{\text { Bume f. Wherema }}{\text { B. J. Wiersma, AUTHOR Date: } 4 / 27 / 92}$ Materials Applications and Corrosion Technology Group Materials Technology Section EQUIPMENT \& MATERIALS TECHNOLOGY DEPARTMENT - SRTC

B. L. LEWIS, CUSTOMER

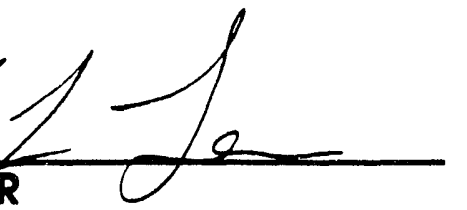

Date: $5 / 1 / 92$

WASTE MANAGEMENT TECHNOLOGY (H-ATEG)

G. R. Cóskey, Jr., TECHNIGAL REVIEWER

Serae Ecoslaug, A

Materials Applications and Corrosion Technology Group

Materials Technology Section

EQUIPMENT \& MATERIALS TECHNOLOGY DEPARTMENT - SRTC

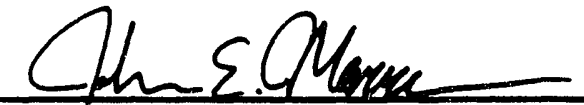

J. E.Marra, MANAGER

Materials Appllcations and Corrosion Technology Group

Materials Technology Section

EQUIPMENT \& MATERIALS TECHNOLOGY DEPARTMENT - SRTC

T. L. Capeletti, MANAGER

Materials Technology Section

EQUIPMENT \& MATERIALS TECHNOLOGY DEPARTMENT - SRTC 
WSRC-TR-92-229 (U)

THIS PAGE INTENTIONALLY LEFT BLANK 


\title{
CONSTANT EXTENSION RATE TENSILE TESTS ON 304L STAINLESS STEEL IN SIMULATED HAZARDOUS LOW-LEVEL WASTE (U)
}

\author{
b $y$ \\ B. J. Wiersma \\ Westinghouse Savannah River Company \\ Savannah River Site \\ Aiken, SC 29808
}

\section{SUMMARY}

New waste tanks which handle hazardous low-level waste were proposed to be constructed in $\mathrm{H}$-area. The candidate material for the tanks is AISI Type 304L (304L) stainless steel. Constant extension rate tensile (CERT) tests were conducted to assess the susceptibility of 304L to stress-corrosion cracking (SCC) in these waste solutions. The tests demonstrated that $304 \mathrm{~L}$ was not susceptible to SCC in simulated wastes. Based on these tests and previous pitting corrosion studies $304 \mathrm{~L}$ is a suitable material of construction for the new tanks.

Comparison tests in the same simulants were performed on A537 carbon steel (A537), a material that is similar to material of construction for the current tanks. Stress-corrosion cracking was indicated in two of the simulants. If carbon steel tanks are utilized to handle the hazardous low-level wastes, inhibitors such as nitrite or hydroxide will be necessary to prevent corrosion.

\section{INTRODUCTION}

Currently Type IV waste tanks (21-23) are available for low-level waste operations. These tanks are constructed of A212 Grade B carbon steel, are single shell, and cannot be inspected at the outer wall. Due to the lack of secondary containment, Waste Management will retire these tanks as soon as possible. A proposed project would provide two new tanks to receive and recycle wash waters to the In-Tank Precipitation (ITP) and Sludge Processing (SP) waste tanks. A third tank would be necessary to serve as a hold tank between the Receiving Basin for Offsite Fuels (RBOF) and the tank 32 cesium removal column. At this time 
the project (Project No. S-2859) has been suspended and may be cancelled.

Carbon steel tanks require inhibitors, such as nitrite or hydroxide, to mitigate corrosion. 1 To reduce the amount of surveillance and inhibitor additions, AISI Type $304 \mathrm{~L}$ stainless steel $(304 \mathrm{~L})$ was recommended as the material of construction for the new tanks. ${ }^{2}$ Additional design features, such as the concrete vault in which the tanks will be encased, provide secondary containment and risers from which the primary tank wall may be inspected.

A review of the environmental conditions which may occur within these tanks suggested that the chloride, fluoride, and chromate concentrations may induce either pitting and/or stress corrosion cracking (SCC) of 304L. ${ }^{3}$ A corrosion testing program was conducted to evaluate the performance of $304 \mathrm{~L}$ in the low level waste environments.4,5,6 Cyclic potentiodynamic polarization, coupon immersion, and electrochemical impedance spectroscopy tests were performed in simulated waste solutions to investigate the pitting susceptibility of 304L. All of these tests indicated that $304 \mathrm{~L}$ was not susceptible to pitting in the waste solutions. Comparison tests with A537 carbon steel (A537) however, indicated that the carbon steel would be susceptible to attack in the dilute wash waters and solutions from RBOF which had a high nitrate concentration.

Constant extension rate tensile (CERT) tests were performed to evaluate the susceptibility of $304 \mathrm{~L}$ to SCC in the waste solutions. As a comparison, the tests were also conducted on A537 carbon steel. This report documents the results of these tests.

\section{EXPERIMENTAL PROCEDURE}

The CERT tests were performed on a Cortest Corrosion Fatigue System. The system included a load cell, a linear variable displacement transducer (LVDT), a signal conditioner for both the load cell and the LVDT, and a temperature controller. Cortest software with a personal computer was utilized for test control and data acquisition A hightemperature vessel constructed of Hastelloy C-276 lids with pyrex chamber walls was used to contain the solution. Additional information on the set-up and operation of the unit is included in NRTSC technical procedure TP-91-034.7 
The tests were conducted in simulants of the actual waste solutions. The solutions included simulants of wash waters from ITP and SP and three solutions from RBOF: resin regeneration wash waters (RR), tritium target cleaning (TTC) solution, and cask decontamination (CD) solutions. These simulants were chosen because of their halide content or minimum inhibitor content. Table 1 lists the components and the molar anion concentrations of the simulants. The solutions were not inhibited to meet technical standard requirements. CERT tests were also performed in oil so that comparisons between fracture surfaces and mechanical behavior parameters obtained from tests in the simulants could be compared with results from tests in an inert environment. The tests were conducted at the maximum expected solution temperature in the tanks, $60^{\circ} \mathrm{C}$.

Round bar tensile specimens with a one inch gage length and 0.25 inch diameter were employed in the tests. The specimen dimensions and design were taken from ASTM Standard E8. The 304L specimens were tested in the as-received and furnace-sensitized conditions. The heat treatment was performed to simulate the microstructure of weld heat affected zones. Maximum sensitization, as determined by Electrochemical Potentiodynamic Reactivation (EPR), was achieved after heat treating a specimen at $650^{\circ} \mathrm{C}$ for 6 hours. Compositions of the $304 \mathrm{~L}$ and A537 specimens are listed in Table 2.

At the conclusion of the tests Scanning Electron Microscopy (SEM) and optical microscopy were used to investigate the fracture surface and the gage length for cracks. The ultimate tensile strength, elongation at failure, and the reduction of area were determined from stress-strain curves and measurements on the failed specimens. The results of these tests are recorded in laboratory notebook WSRC-NB-91-43.

\section{RESULTS}

The CERT technique provides a rapid assessment of a material's susceptibility to SCC. For this technique a tensile specimen is immersed in a suspected corrosive environment and strained to failure on a tensile load frame. The CERT test has two advantages over other SCC laboratory tests. Unlike constant load tests, CERT tests provide absolute results; either ductile failure due to mechanical stresses or brittle cleavage due to SCC. Secondly, they are more rapid than the other tests unless the strain rate is very slow. 
The key parameter for the CERT tests is the strain rate. SCC behavior is generally detected within a critical strain rate range $\left(10^{-4}-10^{-7} \mathrm{~s}^{-1}\right)$. At strain rates faster than $10^{-4} \mathrm{~s}^{-1}$, the mechanism for dimpled rupture (i.e., ductile failure) occurs at a rate much faster than the corrosion reaction occurs thus concealing any SCC behavior. Ductile failure may also occur at strain rates below $10^{-7} \mathrm{~s}^{-1}$ since passivation reactions may inhibit the corrosion reactions and hide SCC behavior. For the tests on $304 \mathrm{~L}$, a strain rate of $10^{-6} \mathrm{~s}^{-1}$ was selected based on a literature review which indicated that stainless steels in chloride environments exhibited cracking at this rate. ${ }^{8}$ The comparison tests on A537 were also performed at this strain rate.

Table 3 summarizes test results including the metallographic analysis and the strength and ductility measurements. The results indicate that $304 \mathrm{~L}$ in both the as-received and furnace-sensitized conditions was not susceptible to SCC in any of the simulants. However, for A537, indications of SCC were observed in the resin regeneration wash and the cask decontamination solution.

Metallographic examination of the specimen fracture surface and gage length is necessary for positive identification of SCC. The fracture surface provides an indication of the mode of fracture. SCC will result in brittle cleavage, while ductile failure will result in dimpled rupture. Ductile behavior is also revealed by a "cup and cone" appearance of the gage length at the fracture location. SCC on the other hand results in a sheared appearance at the fracture location and the presence of secondary cracks along the gage length. The secondary cracks promote premature failure of the specimen due to localization of the stress and the corrosive solution within the crack.

Figure 1 is an SEM micrograph which shows the fracture surface of a furnace-sensitized 304L specimen tested in the cask decontamination waste solution. The dimpled rupture observed was typical of the results obtained for both as-received and furnace-sensitized 304L in all of the simulants. All 304L specimens had a "cup and cone" appearance and had no secondary cracks.

The A537 specimen exposed to the cask decontamination solution is shown in Figure 2. Most of the surface appeared to have failed by dimpled rupture. However, the dark area in the left hand corner of the micrograph is a corrosion spot which most likely occurred as solution seeped in through cracks in the gage length and then attacked the 
surface. Figure 3 shows the gage length of the carbon steel specimen tested in the cask decontamination solution. The specimen had a sheared appearance and several secondary cracks along the gage length.

Mechanical properties such as the ultimate tensile strength, elongation at failure, and reduction of area are also used to evaluate SCC susceptibility. These properties are measured from the stress-strain curves and the failed specimens. A reduction in the properties with respect to those in an inert environment is an indication of SCC. Figure 4 shows the stress-strain curves for furnace-sensitized 304L in the simulated environments and oil. No difference in the ultimate tensile strength or elongation at failure vas observed. Table 3 also indicates that there was not a significant change in the reduction of area. Figure 5 shows the stress-strain curves for A537 in the simulated wastes and oil. A slight reduction in the elongation at failure for both the resin regeneration and cask decontamination solutions was seen. Table 3 also indicates that there was a significant decrease in the reduction of area for the specimen immersed in the cask decontamination solution.

There are two explanations for the resistance of 304L in these waste solutions. First, there is a high ratio of inhibitive anions (nitrate, nitrite, and hydroxide) to aggressive anions (chloride, fluoride, and chromate). Phillips and Singley 9 have shown that a molar ratio of $\mathrm{NO}_{3}{ }^{-}$ $/ \mathrm{Cl}^{-}>1$ prevents cracking as long as the $\mathrm{pH}$ remains above 8 . Table 1 shows that all simulants meet this criteria. Second, the tests are conducted at a relatively low temperature for SCC susceptibility which increases markedly with temperature. The test temperature of $60^{\circ} \mathrm{C}$ is moderate and unlikely to promote SCC of 304L in these waste solutions.

Nitrate stress corrosion cracking has been observed in the carbon steel waste tanks at SRS in uninhibited wastes. 10 Thus, the attack of the A537 in the cask decontamination solution was expected, since the solution has a high nitrate ion concentration and contains no inhibitors. Attack was also indicated in the resin regeneration solution. This solution was more dilute than the unwashed ITP and SP wash waters. Previous tests showed that, in addition to the resin regeneration and cask decontamination wastes, A537 was more susceptible to attack in dilute wash waters than in unwashed wash waters. 5 This result would lead one to suspect that A537 may be more susceptible to SCC if the dilute wash waters are uninhibited. Therefore, 
if carbon steel waste tanks were to be used for storing these low-level wastes addition of nitrite and hydroxide inhibitors would be prudent.

\section{CONCLUSIONS}

CERT tests demonstrated that $304 \mathrm{~L}$ is not susceptible to SCC in any of the simulated low-level waste environments. These results coupled with the results from the pitting studies demonstrate that $304 \mathrm{~L}$ is a suitable material of construction for the new waste tanks. A537, however, was susceptible to both SCC and pitting attack in some of the simulated environments. If carbon steel is to be used for the new tanks, the wastes should be inhibited with nitrite and hydroxide. 


\section{REFERENCES}

1. DPST-241-3.01 (May 16,1988), 5.01 (March 2, 1988), and 5.03 (Rev. 1, December 19,1990).

2. G. M. Johnson to D. M. Bove, "Savannah River Plant - Waste Management Projects Hazardous Low Level Waste Processing Tanks (FY 1990 Line Item) CAB Basic Data - Revision 1", WCC-87-363, September 18, 1987.

3. R. S. Ondrejcin to J. E. Black, "Corrosion Program for Hazardous Low Level Waste Tanks", DPST-88-663, June 24,1988.

4. J. I. Mickalonis to D.T. Hobbs, "Corrosion Study of Replacement Materials for Hazardous Low Level Waste Processing Tanks", WSRC-TR-90-74-1, January 31, 1990.

5. B. J. Wiersma and J. I. Mickalonis, "Corrosion Study of Replacement Materials for Hazardous Low Level Waste Processing Tanks", WSRC-TR-91-138, March 28, 1991.

6. B. J. Wiersma to B. L. Lewis, "Coupon Immersion Testing in Simulated Hazardous Low Level Waste", WSRC-TR-91-493, August 22, 1991.

7. B. J. Wiersma, "Constant Extension Rate Tensile Testing of Metallic Materials", TP-91-034, August 26, 1991.

8. A. J. Sedriks,. "Stress Corrosion Cracking Test Methods", NACE,. p. 17, 1990.

9. J. H. Phillips and W. J. Singley, Corrosion, 15, 450t (1959).

10. R. S. Ondrejcin, "Prediction of Stress Corrosion Cracking of Carbon Steels by Nuclear Process Liquid Wastes", DP-1478, August 1978. 
Table 1.

Molar Anion Compositions of Low Level Hazardous Waste

\begin{tabular}{|c|c|c|c|c|c|}
\hline Solution & ESP & ITP & RR & TTC & C D \\
Number & 1 & 4 & 8 & 11 & 13 \\
\hline $\mathrm{pH}$ & 13.7 & 13.5 & 12.7 & 12.4 & 12.5 \\
\hline $\mathrm{OH}^{-}$ & 2.1 & 1.3 & 0.15 & - & - \\
$\mathrm{CO}_{3}=$ & 0.1 & 0.16 & 0.098 & - & - \\
$\mathrm{NO}_{2-}^{-}$ & 1.1 & 0.6 & 0.07 & - & - \\
$\mathrm{NO}_{3}^{-}$ & 1.4 & 2.0 & 0.7 & - & 4.6 \\
$\mathrm{Cl}^{-}$ & 0.022 & 0.022 & 0.0013 & - & - \\
$\mathrm{F}^{-}$ & 0.011 & 0.015 & - & - & 0.039 \\
$\mathrm{SO}_{4}=$ & 0.095 & 0.14 & 0.0079 & - & - \\
$\mathrm{Al}\left(\mathrm{OH}_{4}\right)_{4}^{-}$ & 0.3 & 0.31 & 0.007 & - & 0.26 \\
$\mathrm{C}_{2} \mathrm{O}_{4}=$ & 0.0051 & 0.014 & - & - & - \\
$\mathrm{CrO}_{4}=$ & 0.0021 & 0.0033 & 0.00084 & 0.013 & - \\
$\mathrm{MOO}_{4}=$ & 0.00027 & 0.00043 & - & - & - \\
$\mathrm{SiO}_{3}=$ & 0.0021 & 0.0038 & 0.00058 & - & - \\
$\mathrm{PO}_{4}^{-3}$ & 0.0058 & 0.0085 & 0.014 & 0.22 & - \\
\hline
\end{tabular}

\section{Notes:}

Solution Designation

ESP-Extended Sludge Processing slurry

ITP-In-Tank Precipitation slurry

RBOF-Receiving Basin for Off-site Fuels wastes:

$\mathrm{RR}-$ Resin Regeneration waste

TTC-Tritium Target Cleaning waste

CD-Cask Decontamination waste

Table 2.

Analysis of Materials Tested (wt. \%)

\begin{tabular}{|ccccccccccc|}
\hline & $\mathrm{C}$ & $\mathrm{Mn}$ & $\mathrm{Si}$ & $\mathrm{P}$ & $\mathrm{S}$ & $\mathrm{Cr}$ & $\mathrm{Ni}$ & $\mathrm{Mo}$ & $\mathrm{Fe}$ & $\mathrm{Cu}$ \\
\hline 304L & .025 & 1.34 & .38 & .032 & .026 & 18.3 & 8.96 & 0.35 & bal. & 0.43 \\
A537 & 0.22 & 1.25 & .22 & .022 & .016 & 0.17 & 0.17 & .03 & bal. & 0.28 \\
\hline
\end{tabular}


Table 3.

Summary of CERT Results

\begin{tabular}{|c|c|c|c|c|c|}
\hline Material & Solution & $\begin{array}{c}\text { Tensile } \\
\text { Streng th } \\
\text { (psi) }\end{array}$ & $\begin{array}{c}\text { Strain at } \\
\text { failure }\end{array}$ & $\begin{array}{c}\text { Reductio } \\
\text { n of } \\
\text { Area (\%) }\end{array}$ & $\begin{array}{c}\text { Fracture } \\
\text { Mode }\end{array}$ \\
\hline 304L-AR & ESP & 89,200 & 0.5703 & 77.5 & Ductile \\
\cline { 2 - 6 } & ITP & 92,000 & 0.539 & 77.7 & Ductile \\
\cline { 2 - 6 } & RR & 87,000 & 0.5612 & 79.4 & Ductile \\
\cline { 2 - 6 } & TTC & 86,800 & 0.544 & 77.5 & Ductile \\
\cline { 2 - 6 } & C D & 88,800 & 0.566 & 75.0 & Ductile \\
\cline { 2 - 6 } & Oil & 88,100 & 0.5572 & 73.3 & Ductile \\
\hline 304L-FS & ESP & 87,000 & 0.5727 & 74.3 & Ductile \\
\cline { 2 - 6 } & ITP & 84,200 & 0.5602 & 77.7 & Ductile \\
\cline { 2 - 6 } & RR & 85,200 & 0.5612 & 75.6 & Ductile \\
\cline { 2 - 6 } & TTC & 86,800 & 0.544 & 77.5 & Ductile \\
\cline { 2 - 6 } & C D & 83,000 & 0.553 & 79.4 & Ductile \\
\cline { 2 - 6 } & Oil & 83,600 & 0.5745 & 80.1 & Ductile \\
\hline A537 & ESP & 73,900 & 0.2764 & 56.4 & Ductile \\
\cline { 2 - 6 } & ITP & 79,100 & 0.2782 & 53.2 & Ductile \\
\cline { 2 - 6 } & RR & 82,200 & 0.2407 & 55.4 & Ductile \\
\cline { 2 - 6 } & TTC & 74,900 & 0.2713 & 55.6 & Ductile \\
\cline { 2 - 6 } & C D & 79,200 & 0.235 & 37.9 & Cracks \\
\cline { 2 - 6 } & Oil & 77,000 & 0.2769 & 57.3 & Ductile \\
\hline
\end{tabular}




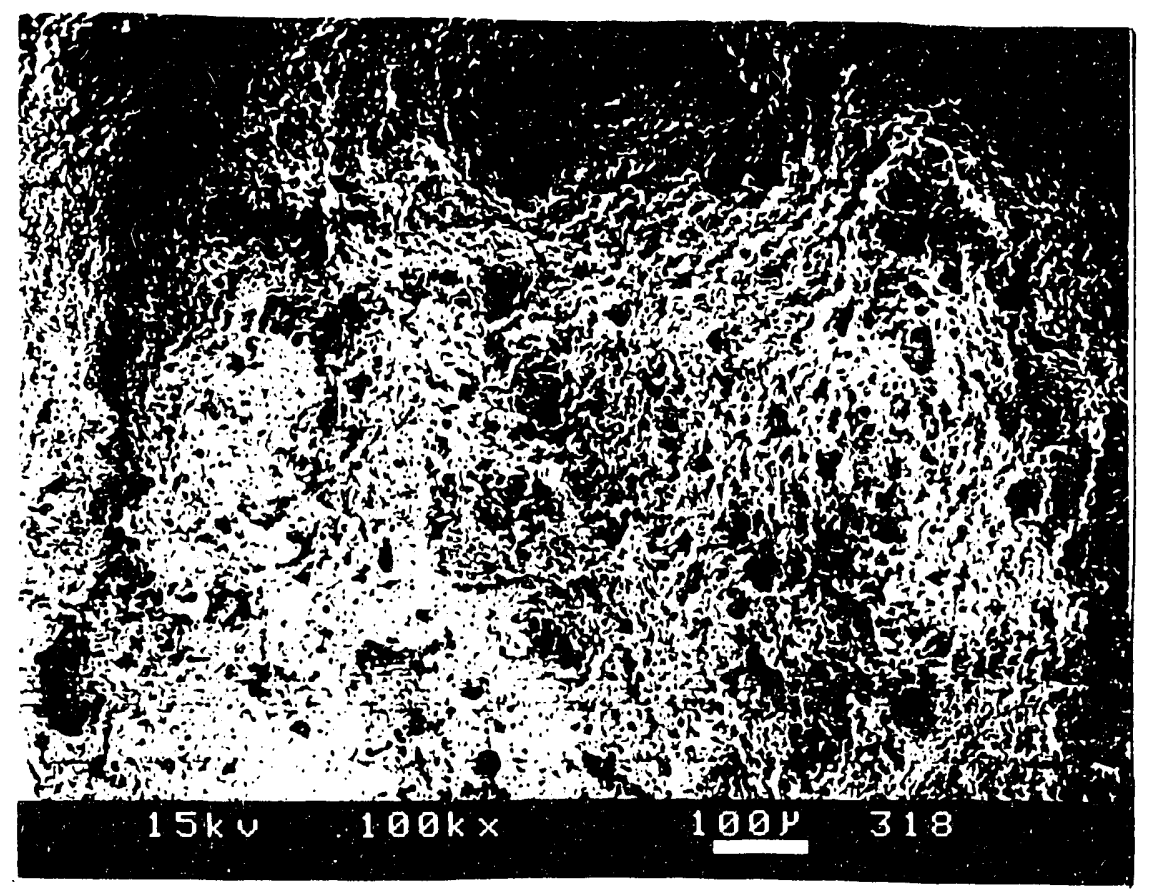

Figure 1. Fracture Surface Of Furnace-sensitized 304L Specimen That Was Immersed In Cask Decontamination Waste (200X).

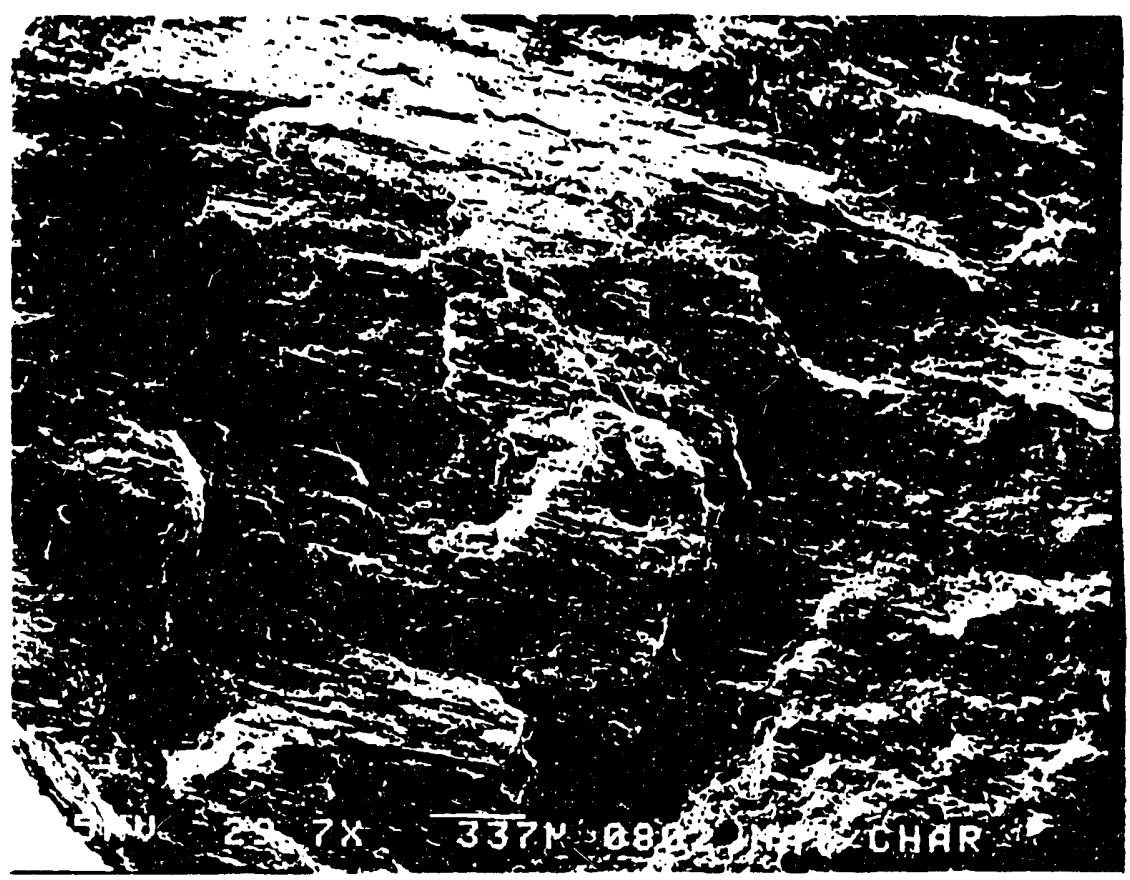

Figure 2. Fracture Surface of A537 Specimen That Was Immersed In Cask Decontamination Waste (30X). 


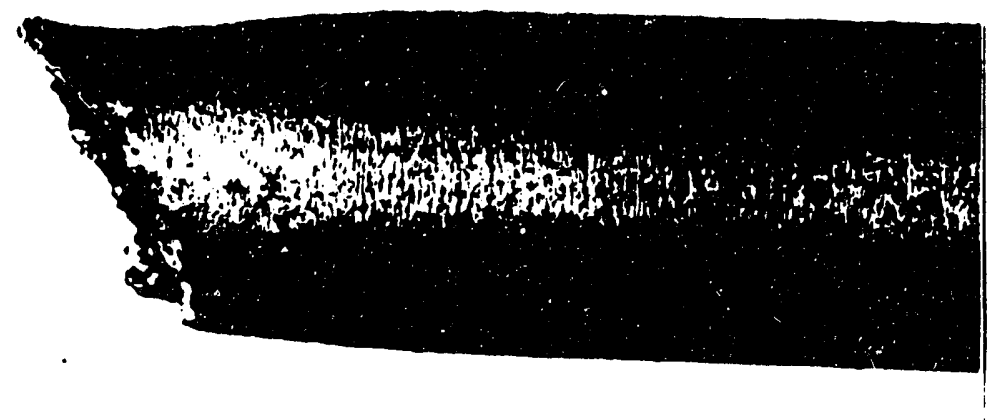

Figure 3. Gage Length Of A537 Specimen That Was Immersed In Cask Decontamination Waste (6X). 


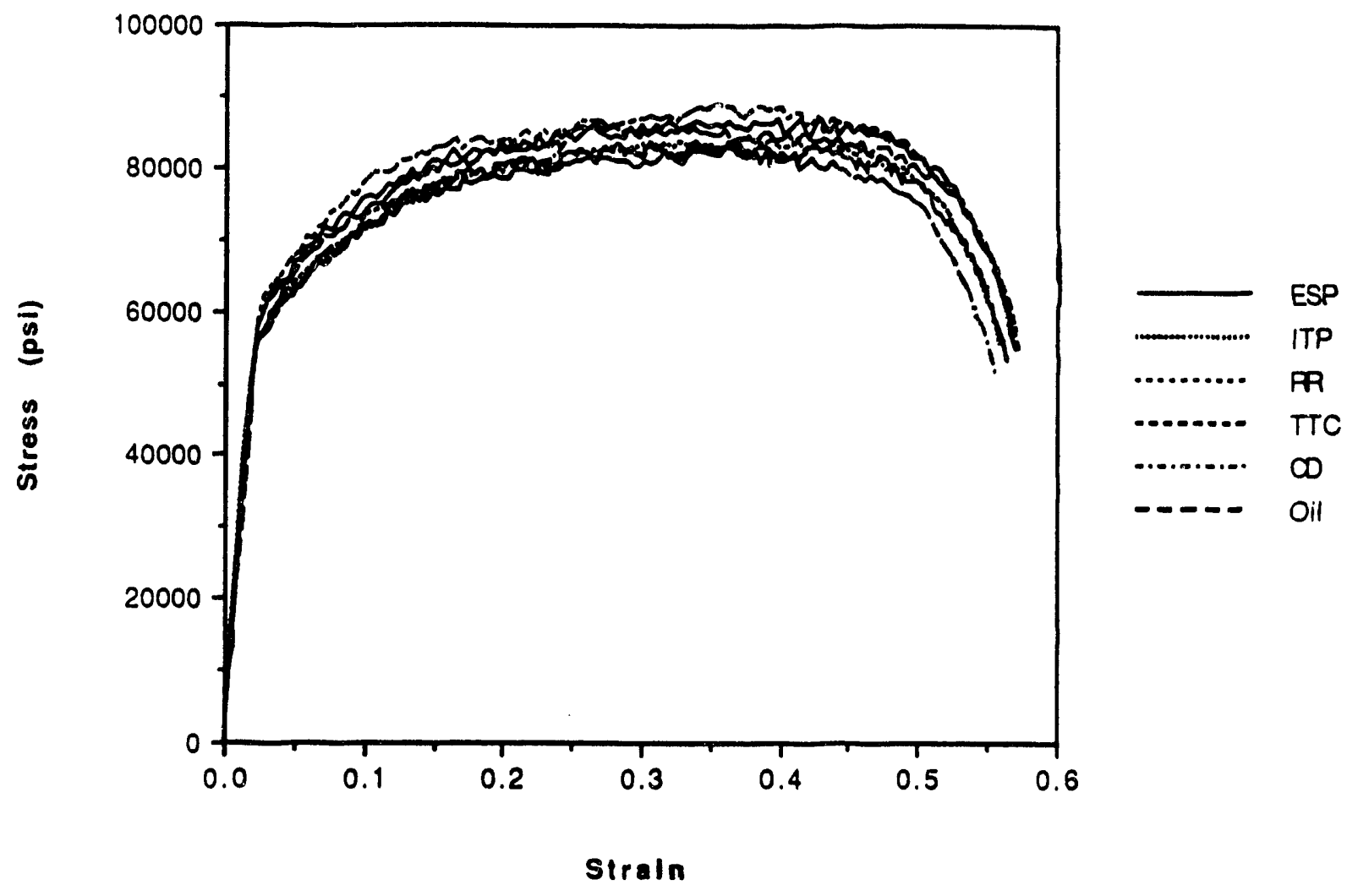

Figure 4. Stress vs. Strain Curves For Furnace Sensitized 304L In Different Waste Solutions. 


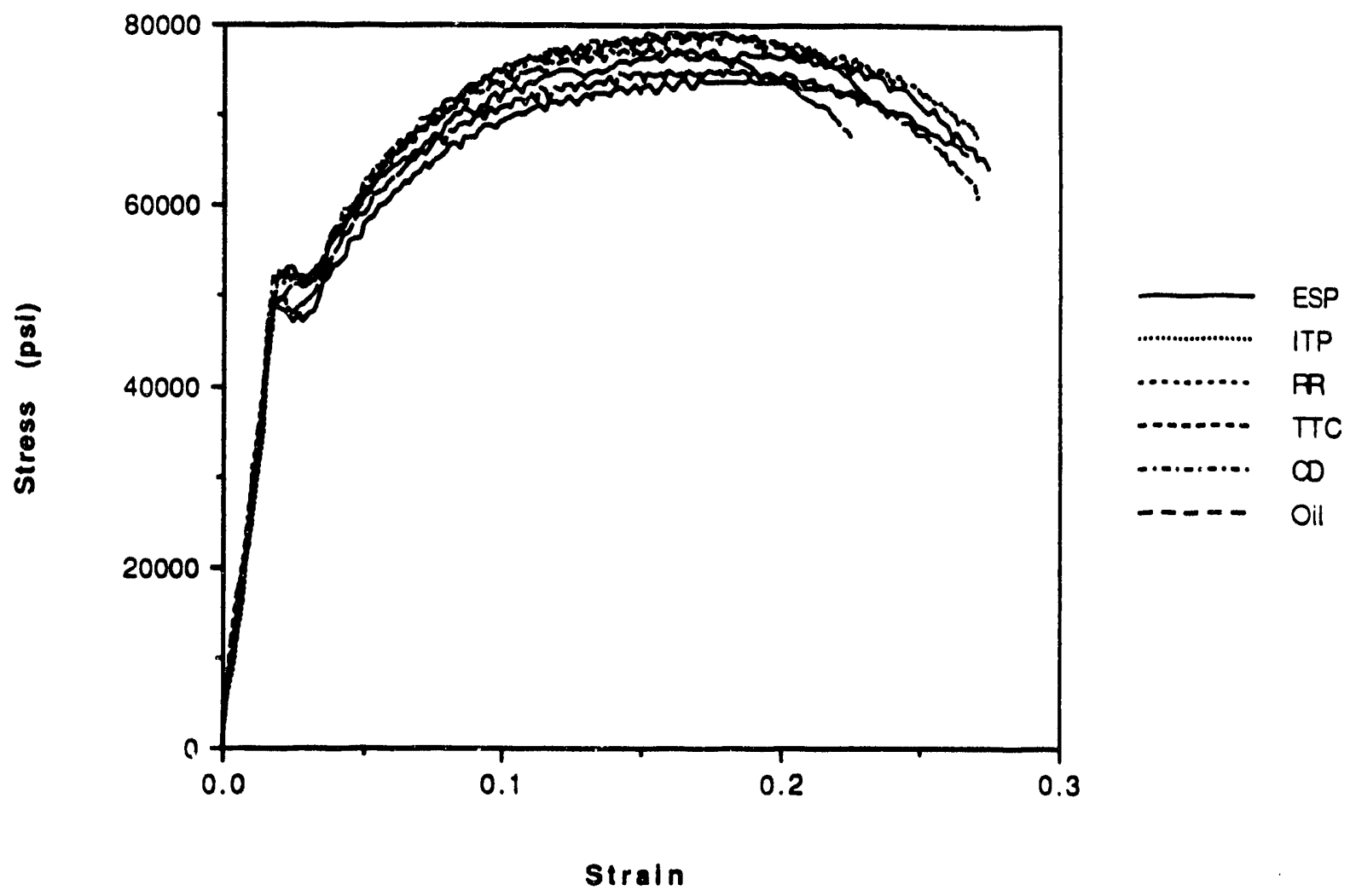

Figure 5. Stress vs. Strain Curves For A537 In The Different Waste Solutions. 
B. J. Wiersma

April 1992
WSRC.TR.92.229

UNCLASSIFIED

THIS PAGE INTENTIONALLY LEFT BLANK 

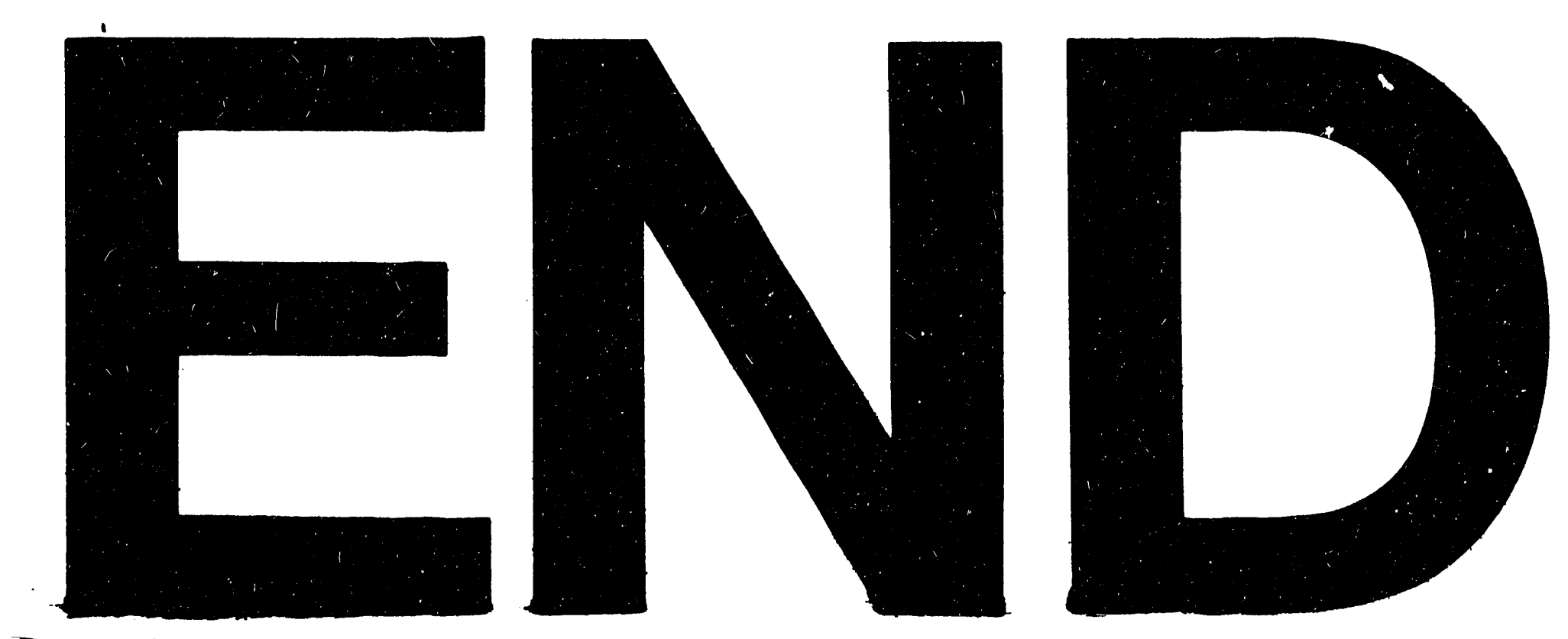

a
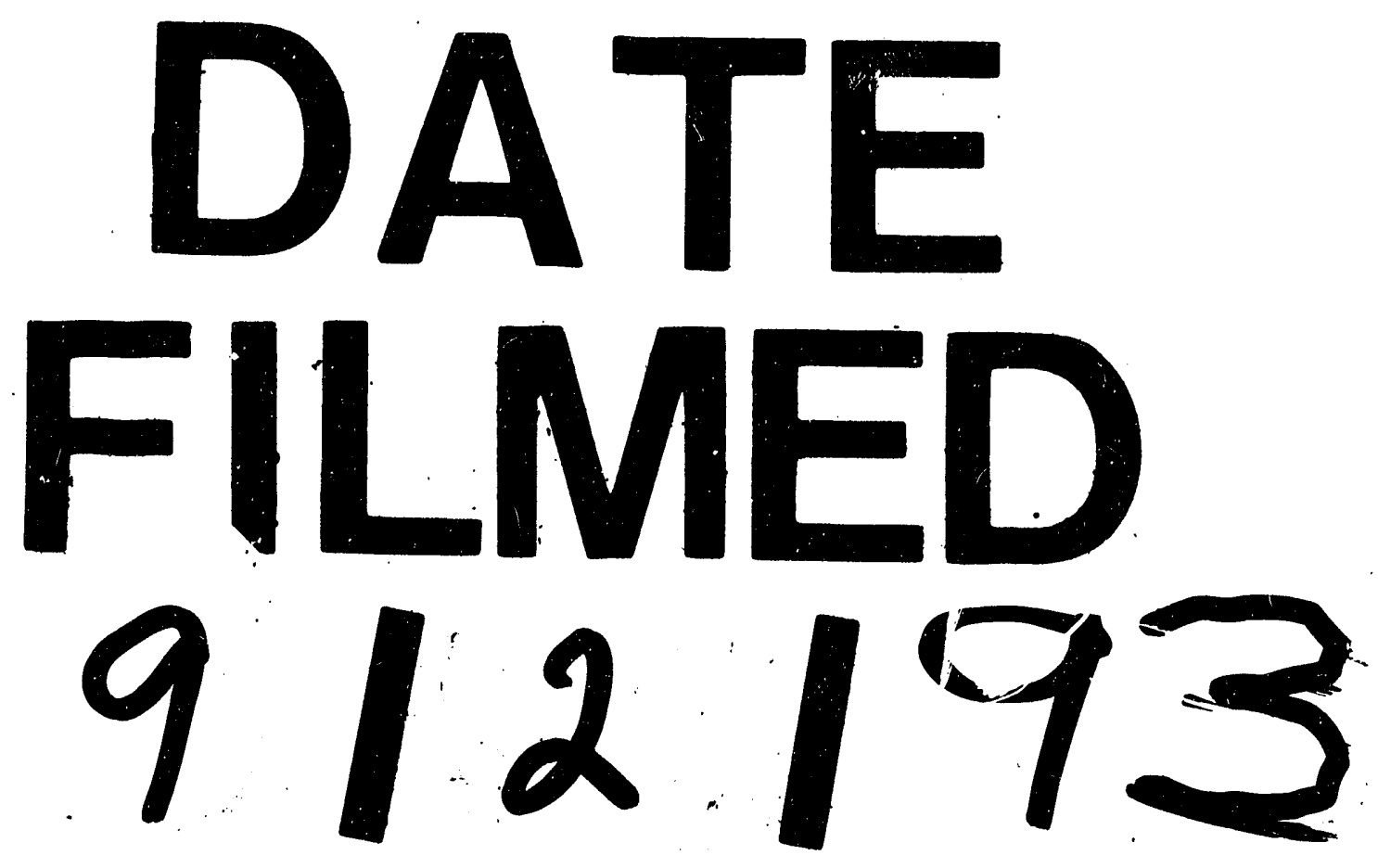
